\title{
Cognitive Style and Teaching Method: The Effect on Students' Writing Performance
}

\author{
Ramli $^{1}$, E Boeriswati ${ }^{2}$, Emzir $^{3}$ \\ 1,2,3 Postgraduate of Universitas Negeri Jakarta \\ ${ }^{1}$ English Education Department, Universitas Lakidende Unaaha \\ ramli15@mahasiswa.unj.ac.id ${ }^{1}$,endry.boeriswati@uj.ac.id²,emzir.unj@unj.ac.id²
}

\begin{abstract}
Teaching method and cognitive style are considered to involve in learners' academic performance. This paper investigates the effect of cognitive style and teaching method on students' writing performance. This experimental study involved 44 participants administered a Group Embedded Figures Test (GEFT) before applying the treatment. The GEFT scores was used to group them into experimental and control classes. The experimental and control classes were taught respectively metaphorming and discovery methods. After 10 meetings, the two groups were administered an essay writing post-test organized in 100 minutes. The data were analyzed statistically using two-way ANOVA at the significant level 0.05 . The findings showed that the experimental group performed better in writing English essay than the control group for fieldindependent students. It implies that teaching methods can benefit students when aligning with their cognitive style dealing with essay writing skill.
\end{abstract}

Keywords: Teaching Method, Metaphorming and Discovery Learning, Cognitive Styles, Essay Writing

\section{INTRODUCTION}

Writing skills are very important for students [1] in their academic performance. Writing is a learning medium as well as a means of expressing and communicating opinions/ideas critically to the phenomena that occur in the surrounding environment. Coffin et al. [2] suggest that writing is a tool of critical thinking, learning and remembering, developing knowledge, communicating, and mastering certain disciplines and can give an idea of students' understanding of a particular scientific field. Thus, English writing skills have implications for academic achievement, the world of work, and student interpersonal communication with the community.

Learning skills in English as a foreign language encounters a number of issues. Writing skill is most difficult among the language skills [1]. Flynn and Stainthorp [3] state that writing skills are recognized as more difficult than reading. This difficulty arises because all the contents of the writing must reflect a substantive idea/information and attract the interest of the reader, students are also required to adhere such the formal rules of language as grammar, cohesion and coherence. Richards and Renandya [4] also stated that writing is the most difficult skill to master by second language learners. The problem is the learners have low ability to produce, organize, and put ideas into text. 
Based on the preliminary observations has been made on the writings and some of the final assignments, the students' writing is still far from adequate observing from both the content and linguistic aspects. Organizing essay, for example, has yet to show the cohesive and coherent writing. In addition, word selection, grammar and syntax errors are still in common. Moreover, the students failed to communicate and develop their idea into good writing. This problem is influenced by several issues. One of them is the teaching method. The success of learning cannot be separated from the compatibility between the methods applied and the way the students learn. This appropriateness will make it easier for students to receive and understand the subject matter. As a result, it implies that there is an effective learning process and maximum learning outcomes when both factors are supporting each one in the process of learning.

As the active participation of students determines the success of learning, the studentcentered learning approach is most possible to apply to promote the success of learning process. Student-centered learning views, rooted from constructivism approach, the students as subjects and should be given a plenty opportunity and space to experience the learning process and explore their knowledge on one hand. On the other hand, lecturers act as facilitators and mentors for students during learning activities. Another issue is learners' style in writing. Some scholars have studied that learning style has implication to academic performance. Witkin and his collogues have studied field-independent/dependent as cognitive styles and the implication to the educational activities. The study found that such cognitive style benefits for a variety of educational issues [5]. Another report suggests that cognitive style especially field independence builds up resilient connection with language competence [6].

Related to the problem above, teaching method and considering the learners' way of study are needed to address. The writing skills are abilities that involve students' cognitive and creative processes. It requires students to think creatively and critically. Consequently, the learning methods that can promote the success in learning writing skills are methods that focus more on the activities and cognitive processes of students. These are found in learning methods adopting the constructivism approach. Aligning with this research, there are two teaching methods focus on the cognitive process of learners, metaphorming and discovery learning methods. The discussion on the two methods are provided in the following section.

\subsection{Metaphorming}

Metaphorming comes from the word meta which is beyond the real world and phora which means transfer. Creative Metaphor is a strategy in order to guide students to think. It emphasizes the individual cognitive processes in learning activities to change something from a situation and meaning into another condition and meaning [7]. It is a process that takes place in our organs which is sometimes known as the unconscious process and aimed at increasing creativity, opening and discovering new things, linking things that appear to be unrelated at all, solving problems and providing solutions, pouring original ideas or criticizing them, enriching learning experiences and improving communication [7, hal. 7]. It emphasizes the cognitive activities of learners in absorbing, understanding, and responding to the learning material provided in the learning process by placing students as learning centers. In addition, this method is based on how to adjust the structure and function of the brain naturally. This natural process will support the occurrence of meaningful learning activities [8].

The metaphorming learning method aims to guide learners in exploring natural links and relationships between various subjects and fields of knowledge [9]. It emphasizes the role of 
learners to build relationships and links between information with other information. Through metaphorming, students are given the opportunity to learn more actively to develop their analytical abilities. Learning using the metaphorming method is done in five steps as follows: First, the connection is the activity of connecting images, symbols, etc. into a complete knowledge, lecturers convey their understanding and objectives of learning to students, and the relationship between material and other fields of science. Second, the discovery stage directs students to find something new such as the implementation of material in everyday life. Third, creation is the stage to create something new or modified. Students can synthesize new paragraphs that are more presentable and argumentative. Fourth, the application as a stage of applying imagination, observation, discovery, development, and new knowledge in English essays. At this stage, students express their new ideas with strong reviews and are compiled in a complete essay. And finally, the revision is done as an effort to correct and evaluate the implementation of learning. Every weakness and deficiency is given a special attention for improvement. The previous discussion implies that this method will be appropriately applied to teach learners in English writing skill.

\subsection{Discovery}

Discovery learning has its roots in the perspective of constructivism to facilitate the creation and management of knowledge and the transfer of knowledge in different contexts [10]. Constructivism believes that learning will take place effectively if the learners seek their own knowledge. Discovery gives learners the opportunity to become autonomous learners in the entire learning process that will effectively help learners find the basic principles of a domain and generalize the knowledge to different tasks and contexts [11] often involves problem-solving situation [12, hal. 188].

According to Richards and Schmidt, discovery learning refers to an approach in learning that is based on several principles, namely: "a) Learners develop processes associated with discovery and inquiry by observing, inferring, formulating hypotheses, predicting and communicating, b) Teachers use a teaching style which supports the processes of discovery and inquiry. c) Textbooks are not the sole resources for learning. d) Conclusions are considered tentative and not final. e) Learners are involved in planning, conducting, and evaluating their own learning with the teacher playing a supporting role [13].

The discussion implies that discovery learning is a method intended to create active learning activities by positioning learners as the main actors and requiring them to play dominant role during the learning process in finding their own knowledge understanding, concepts, theories or ideas based on their own perspectives by giving them an initial information on the subject going to be learned. The rest will be settled by students through the discovery process. The instructor acts as a guide so that the defined learning objectives can be achieved. Therefore, the learning process and results will be meaningful if the knowledge is constructed by the students themselves.

\subsection{Cognitive Style}

In addition to learning methods, cognitive style also affects the success of learning students. Some research results show the effect of learning styles on academic achievement. First, Richards and Schmidt [13] revealed the influence of cognitive style on academic achievement and success. Furthermore, Kahtz and Kling [14] in his study also concluded that students with field-independent cognitive style felt helped by the Computer Assisted Instruction 
learning method and students with field-dependent cognitive styles did not feel helped. Finally, Witkin et al. [5] find that individuals who have field-dependent cognitive styles tend to be superior in learning and remembering social material compared to individuals who are relatively cognitive field-independent. And, individuals with field-independent cognitive style are superior in managing reshaping the environment (field) while individuals who are in fielddependent cognitive style tend to be constrained by the environment it faces.

\subsubsection{Field independent}

Richards and Schmidt [13] say that field-independent cognitive style is a way of a learner who is able to recognize or focus on certain elements and is not influenced by other elements contained in one context and background. Whereas according to Slavin [15], field independence is a cognitive style that can perceive and analyze separate parts in a pattern. People who have a field-independent cognitive style are easier to identify the parts that form a broader pattern. In addition, individuals with field-independent cognitive styles tend to be easier to work on problems related to numbers, science, and problem-solving tasks.

\subsubsection{Field dependent}

According to Richards and Richard, field dependent refers to a learning style in which a learner tends to look at the whole learning task which contains many items. The learner has difficulty in studying a "field" of other items [16]. It suggests that learners who have a fielddependent cognitive style look at things as a whole from various points of view. They have weaknesses in learning something that is in a "field".

Individuals who have a field-dependent cognitive style tend to see a pattern as a whole and tend to have difficulty separating specific aspects of a situation or pattern; and they tend to be oriented towards fellow and social relationships compared to individuals who have fieldindependent cognitive styles. FD type individuals have a tendency to easily remember social information, social relations, and easily work together in groups and are more pleased with subjects in history and literature [15].

People who are field-dependent cognitive style according to Ehrmana and Leaver [17] have a tendency to social relations so they need cooperation to receive, manage, respond to stimuli and solve problems. Their tendency to see things as a whole and the tendency for social relations makes it possible to know and understand complex problems and social relations, of course, require language for communication between the same in their social environment.

The two factors above, learning methods and cognitive styles, are regarded to play a vital role in shaping learners' skill in writing English essay. Based on the description above, the study examines the effectiveness of metaphorming learning method on students' essay in relation to their cognitive styles, field independent and field dependent.

\section{RESEARCH METHOD}

\subsection{Setting}

This research was carried out at English Education Study Program in the Academic Writing course, Universitas Banten Jaya for students of the 2016 taken place from February 2017 - June 2018, academic year 2017/2018. 


\subsection{Design}

This quantitative research uses experimental method with a $2 \times 2$ factorial design. This design is used to determine whether there is an effect of the treatment given to the experimental and control groups. The research involved two groups of students, experimental group and control group, respectively provided with metaphorming learning method for the former and discovery learning method for the latter. Each group was composed of students who have independent and field-dependent cognitive styles in learning.

\subsection{Instruments}

The data collection was carried out by administering two test instruments. The first is essay writing test in English, the Students are provided with a number of topics to choose, one of which is in accordance with the information they have learned, and then asked to write an essay in English consisting of $250-400$ words. Test scoring was assessed based on the criteria had been set based on 5 aspects: content, organization, vocabulary, language use, and mechanics. The essays were assessed based on assessment criteria that have been assigned with a score ranging from $1-5$. The second is a cognitive style instrument called GEFT test developed by Witkin [18]. This test consists of three sections. The first section consists of 7 items intended for training and adaptation before students work on the item test assessed for their cognitive style. The second and third sections each consist of 9 items. In each question, students are asked to find simple figures that are embedded in complex figures. Each item is valued 1 for the correct answer and 0 for the wrong one. Thus, the maximum score is 18 and the lowest score is 0 . The GEFT test will be given in 20 minutes. The more the students answer correctly, the more likely they will be grouped into field-independent style and the lower the GEFT test score they have, the more likely they will be grouped into field dependent styles.

\subsection{Respondents}

All students of the English Language Education Study Program, FKIP, Universitas Banten Jaya were chosen as unreached populations in this study. Meanwhile, the possible populations are students of 2016 in the $4^{\text {th }}$ semester consisting of 4 classes in academic year 2017-2018 by purposive sampling. Among the four classes, 2 classes were selected to involve in the experimental research. One group was treated with metaphorming method as an experimental class and one group was taught with discovery methods as a control one. This selection was carried out using a random technique. Before applying the learning methods, the two groups were tested to identify their cognitive learning styles. This was carried out by administering the Group Embedded Figures Test (GEFT) instrument to each group [18].

\section{RESULT AND DISCUSSION}

The GEFT score administering to the treatment groups revealed that there are 12 fieldindependent students in experimental group and 10 field-independent students in control group. After 8 meetings of writing learning process, they are administered a test of writing essay where the scores range from 1-25. The following table presents the average score of learners who tend to learn in field-independent style in writing essay in both treatment groups. 
Table 1. Essay Scores on the Both Groups

\begin{tabular}{llll}
\hline \multicolumn{1}{c}{ Teaching methods } & Cognitive styles & Mean & N \\
\hline Metaphorming & Field Independent & 20.91 & 12 \\
Discovery & Field Independent & 17.78 & 10 \\
\hline
\end{tabular}

\section{CONCLUSIONS}

The findings confirm that learners' writing performance has relation to the teaching method lecturer applying in the teaching-learning process. It also confirms that the learners' cognitive style of field-independence plays essential role as well. The result shows that metaphorming method (average score $=20.91$ ) benefits more the learners who tend to be field-independent cognitive style than those taught using discovery method (average score $=17.78$ ). Therefore, it suggests that students in field-independent style need to be encouraged to study more independently by applying teaching instruction that promote them to do so. Student creativity will be honed and developed to help compose essays in English. So the role of creativity is key in the learning process by applying metaphorming methods.

\section{ACKNOWLEDGEMENT}

I gratefully express my gratitude to Director of Research and Society Service (DRPM) of Ministry of Research, Technology, and Higher Education (RISTEKDIKTI) for the Doctoral Degree Grant, year 2018 in the completion of this research.

\section{REFERENCES}

[1] C. Zhang, "Effect of instruction on ESL students' synthesis writing," J. Second Lang. Writ., vol. 22, no. 1, hal. 51-67, 2013.

[2] C. Coffin, M. J. Curry, S. Goodman, A. Hewings, T. M. Lillis, dan J. Swann, Teaching Academic Writing: A toolkit for higher education. London and New York: Routledge, 2005.

[3] N. Flynn dan R. Stainthorp, The Learning and Teaching of Reading and Writing. England: Whurr Publishers Limited, 2006.

[4] J. C. Richards dan W. A. Renandya, Methodology in Language Teaching: An Anthology of Current Practice. Cambridge: Cambridge University Press, 2002.

[5] H. A. Witkin, C. A. Moore, D. Goodenough, dan P. W. Cox, "Field-Dependent and Field-Independent Cognitive Styles and Their Educational Implications," Rev. Educ. Res., vol. 47, no. 1, hal. 1-64, 1977.

[6] M. Rezaee dan M. Farahian, "The Case Study of a Field-Independent English Language Learner," Procedia - Soc. Behav. Sci., vol. 47, hal. 114-119, 2012.

[7] T. Siler, Think Like A Genius: The Ultimate User's Manual for Your Brain. The Unated State and Canada: Bantam Booka, 1999.

[8] E. Jensen, Brain-Based Learning: The New Paradigm of Teaching. Thausand Oaks: Corwin Press, 2008.

[9] P. Jensen, “The ArtScience ${ }^{\circledR}$ Program Status Report," 2001. [Daring]. Tersedia pada: http://www.discover.arizona.edu/resoArtSci_Mus.htm. [Diakses: 20-Des-2018]. 
[10] N. J. Salkind, "Encyclopedia of Educational Psychology," Encyclopedia of Educational Psychology, vol. 1 \& 2. SAGE Publications Ltd., Los Angeles, 2008.

[11] W. van Joolingen, "Cognitive Tools for Discovery Learning," Int. J. Artif. Intell. Educ., vol. 10, hal. 385-397, 1999.

[12] R. C. Richey, J. D. Klein, dan M. W. Tracey, The Instructional Design Knowledge Base: Theory, Research, and Practice. New York and London: Routledge, 2011.

[13] J. C. Richards dan R. Schmidt, Longman Dictionary of Language Teaching \& Applied Linguistics, 4th ed. Great Britain: Pearson Education, 2010.

[14] A. W. Kahtz dan G. J. Kling, "Field-dependent and Field-independent Conceptualisations of Various Instructional Methods with an Emphasis on CAI: a qualitative analysis," Educ. Psychol. An Int. J. Exp. Educ. Psychol., vol. 19, no. 4, hal. 413-428, 1999.

[15] R. E. Slavin, Educational Psychology: Theory and Practice, 8th ed. Boston: Pearson Education, 2006.

[16] J. C. Richards dan R. Schmidt, Longman Dictionary of Language Teaching and Applied Linguistics, 3rd ed. Great Britain: Pearson Education Limited, 2010.

[17] M. Ehrmana dan B. Lou Leaver, "Cognitive Styles in the Service of Language Learning," System, vol. 31, hal. 393-415, 2003.

[18] H. A. Witkin, P. K. Oltman, E. Raskin, dan S. A. Karp, Group Embedded Figures Test. Palo Alto, Calif.: Consulting Psychologists Press, 1971. 